\title{
Malaria transmission in Libreville: results of a one year survey
}

\author{
Jean-Romain Mourou', Thierry Coffinet ${ }^{2}$, Fanny Jarjaval ${ }^{2}$, Christelle Cotteaux ${ }^{2}$, Eve Pradines ${ }^{2}$, Lydie Godefroy ${ }^{2}$, \\ Maryvonne Kombila ${ }^{1}$ and Frédéric Pagès ${ }^{2^{*}}$
}

\begin{abstract}
Background: In Gabon, vector transmission has been poorly studied. Since the implementation of the Roll Back malaria recommendations, clinical studies have shown a decline in the burden of malaria in Libreville, the capital city of Gabon. To better understand the transmission dynamic in Libreville, an entomological survey was conducted in five districts of the city.

Methods: Mosquitoes were sampled by human landing collection during 1 year in five districts of Libreville: Alibandeng, Beauséjour, Camp des Boys and Sotega. Mosquitoes were identified morphologically and by molecular methods. The Plasmodium falciparum circumsporozoïte indices were measured by ELISA, and the entomological inoculation rates (EIR) were calculated for all areas. Molecular assessments of pyrethroid knock down resistance $(\mathrm{kdr})$ and of insensitive acetylcholinesterase resistance were conducted.
\end{abstract}

Results: A total of 57,531 mosquitoes were caught during 341 person-nights (161 person-nights indoor and 180 person-nights outdoor) among which, 4,223 were Anopheles gambiae s.l. The average Human Biting Rate fell from 15.5 bites per person during the rainy season to 4.7 during the dry season. The An. gambiae complex population was composed of An. gambiae s.s molecular form S (99.5\%), Anopheles melas (0.3\%) and An. gambiae s.s. form M (0.2\%). Thirty-three out of 4,223 An. gambiae s.l. were found to be infected by $P$. falciparum (CSP index $=0.78 \%$ ). The annual EIR was estimated at 33.9 infected bites per person per year ranging from 13 in Alibandeng to 88 in Sotega. No insensitive AChE mutation was identified but both kdr-w and kdr-e mutations were present in An. gambiae molecular form S with a higher frequency of the kdr-w allele (76\%) than the kdr-e allele (23.5\%).

Conclusion: Malaria transmission in Libreville occurred mainly during the rainy season but also during the dry season in the five districts. Transmission level is high and seems to be very heterogeneous in the town. Interestingly, the highest EIR was recorded in the most central and urbanized quarter and the lowest in a peripheral area. The decrease of transmission usually seen from peri-urban areas to urban centers is probably more dependent of the socio-economic level of a quarter than of its location in the city. Urban malaria control programmes need to consider the socio economic level of an area rather than the location in the city in order to determine the areas most favourable to malaria transmission.

\section{Background}

Urbanization is increasing in Africa resulting in a change in the epidemiology of malaria [1]. One characteristic of African cities is the maintenance in urban areas of traditional rural practices, such as housing and food crops, that create favorable conditions for malaria

\footnotetext{
* Correspondence: frederic_pages@yahoo.com

UMR 6236, Unité d'entomologie médicale, IRBA antenne Marseille, GSBDD Marseille Aubagne, 111 avenue de la corse BP 40026, 13568 Marseille Cedex 2, France

Full list of author information is available at the end of the article
}

transmission [2-4]. Marked intra-city variations in the burden of malaria exist due to differences in urbanization level, in equipment, in housing and in socio-economic level between districts [5]. Entomological inoculation rates can vary from 0 to 54 infective bites per man per year between Ouagadougou and Dar es Salaam and can double between the centre and periphery of a same city [6]. Currently, 40 African cities have more than one million inhabitants and in 2003, 39\% of Africans lived in cities [7]. Keiser et al. estimated urban malaria morbidity to be between 25 and 100 million

\section{Biomed Central}


cases, amounting to between six and $28 \%$ of the total annual incidence [6]. According to the United Nations (UN) projections, by 2025, over 800 million people, about $54 \%$ of the continent's population, will live in urban areas (1). Thus, urban malaria has become an emerging public health problem in Africa and has become the subject of many studies to better understand its determinants, suggest preventive measures and appropriate control [8-15].

Gabon has a population, estimated at 1,534,381 inhabitants according to the Constitutional Court [16]. Despite it has one of the lowest population densities of any country in Africa, it is not spared by the demographic change that is affecting the majority of the continent. Due to a rural exodus, the majority (about $80 \%$ ) of the population is urban or semi-urban [16]. Libreville alone has 579,577 inhabitants: $36.36 \%$ of the total population and $47.21 \%$ of the urban population [16]. Libreville is flanked by the Atlantic Ocean to the west and is irrigated by numerous rivers to the east. In Gabon, the burden of malaria has often been determined from clinical and laboratory data, by morbidity and mortality measurements, particularly at the Libreville Hospital Centre and in the Medical Research Unit of the Albert Schweitzer Hospital in Lambaréné $[17,18]$. Vector transmission has been poorly studied [19-21]. A preliminary study conducted between December 2006 and April 2007, during the rainy season in the French military base in Libreville (Camp de Gaulle), revealed the presence of Anopheles gambiae s.l. and showed a low transmission of four Plasmodium falciparum-infected bites per person per year [22]. This same study confirmed the high prevalence of molecular markers of resistance to pyrethroids described by Pinto et al. in 2006 and showed the presence of molecular markers of resistance to organophosphates and carbamates [23]. The military authorities have implemented an extensive anti-larval and anti-imago mosquito control in the camp, so the transmission level was relatively very low. However, this is probably not the reflect of the situation in the surroundings neighborhoods as it has been already shown for the non-anopheline mosquito vectors during the Chikungunya outbreak in 2007, when their density was 12 times higher outside the camp [24]. Reliable entomological data on the levels of transmission of malaria in different districts in Libreville is scant, despite the fact that it contains a third of the country's population.

Malaria in Libreville is a major public health problem as in other Central African capitals. In the 2000s, P. falciparum was responsible for $15 \%$ to $40 \%$ of medical care for fever in children under 11 years old [25]. During the same period, the prevalence of infection with $P$. falciparum and anemia were respectively $53.6 \%$ and $53 \%$ among pregnant women [26]. In 2005, artemisinin-based combination therapy (ACT) was adopted for uncomplicated malaria, long-lasting nets impregnated with pyrethroids (deltamethrin) were distributed to high risk groups (pregnant women and children under 5 years of age) and a strategy of intermittent preventive treatment with sulphadoxine-pyrimethamine for pregnant women (IPTp-SP) was made available in all health centers in the country [27]. Since then, clinical studies have shown a decline in the burden of malaria in Libreville both in pregnant women and in children [25,27]. Currently, data on parasite infection in febrile children aged 5 to 10 years old suggests a direct impact of this strategy on the level of exposure to malaria [25]. To better understand the transmission dynamics of malaria in Libreville, an entomological survey was conducted from December 2008 to January 2010 in five districts.

\section{Methods \\ Study areas}

Libreville was initially partitioned in three areas considering the type of habitat, the location and the socio-economic level: a central zone with high population density and poor living conditions, an intermediate zone located on the coast where most neighborhoods are affluent and a suburban zone, separated from the central area by a highway, less densely populated, with dispersed houses (in between the intermediate and central zone). In each area, a district was randomly chosen in the list of Libreville districts: for the central zone, from July 2009, the district "Sotega" replacing Akébé-Poteau, followed from March to April 2009, for the intermediate zone area the district "Beau-séjour", for the peripheral zone the district "Alibandeng". Another district "Camp des Boys" neighboring the French military base "Camp de Gaulle" situated also in the peripheral area was added. The studied zones are presented and listed in Figure 1. As a specific survey of fevers by district was not possible for logistic reasons, we used data from the Department of Parasitology at the Libreville Medical School to determine the burden of malaria throughout the year. All patients presenting with fever from December 2008 to January 2010 had a blood smear taken.

\section{Climate and rainfall}

Libreville is an equatorial climate characterized by a long rainy season lasting 8 months (interrupted by a short dry season) and a long dry season lasting 4 months. Average temperatures remain relatively constant throughout the course of the year, with average high temperatures at around $30^{\circ} \mathrm{C}$. Rainfall data for 2009 were obtained courtesy of the General Directorate of Meteorology of Gabon and are presented in Figure 2. Annual rainfall was 2945.9 $\mathrm{mm}$ with a monthly average of $245.5 \mathrm{~mm}$ : maximum $(468.7 \mathrm{~mm})$ was seen in October and minimum (25.6 


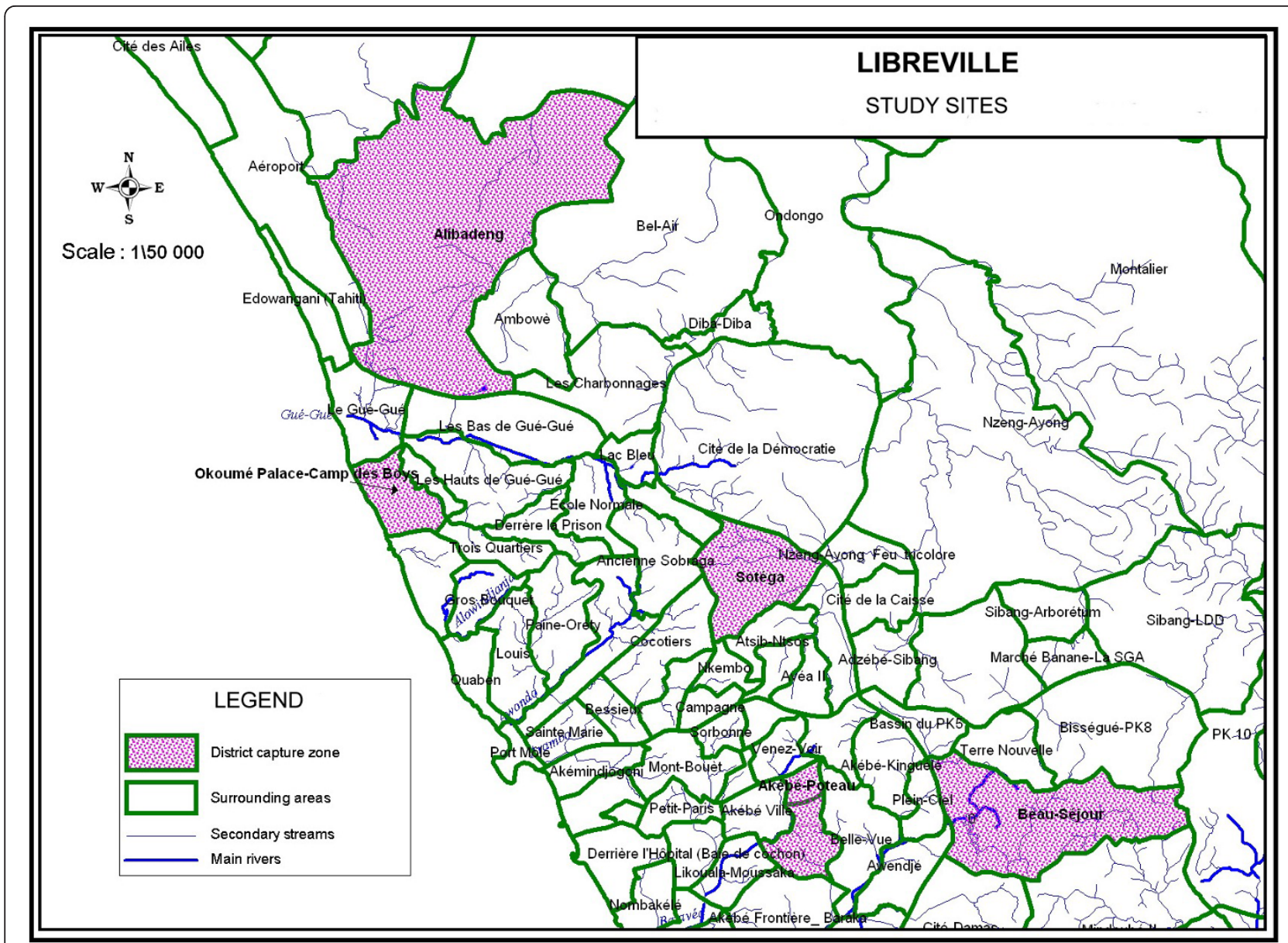

Figure 1 Distribution of the study sites in Libreville.

$\mathrm{mm}$ ) in July. There were two seasons in 2009: a dry season from June to September, with a total rainfall of 67.8 $\mathrm{mm}(16.8 \mathrm{~mm} / \mathrm{month})$ and a rainy season from October to May, with a total rainfall of $2878.8 \mathrm{~mm}(359.85 \mathrm{~mm} /$ month). Despite a decline in rainfall during January-February $(225.75 \mathrm{~mm} / \mathrm{month})$, it was not considered as a short dry season. For the purpose of the analysis, two main seasons were considered: a rainy season and a dry season.

\section{Processing of mosquito collections}

Malaria vectors were sampled using both indoors and outdoors landing collections from December 2008 to January 2010. Collectors gave prior informed consent and received anti-malaria prophylaxis and yellow fever immunization. They were organized in teams of two for each collection point. Workers within a team were replaced every $2 \mathrm{~h}$ from 6:00 p.m. to 7:00 a.m. The teams rotated among the collection points on different nights to minimize sampling bias. In each district, four catching points were selected: two indoors and two outdoors. A capture session was performed every 2 weeks in each district. Occasional difficulties led to the addition or removal of some sessions or capture stations. In total, the capture effort was 341 man-nights: 15 for the district Akébé-Poteau (stopped tracking after 2 months), 60 for the district the "Sotéga", 97 for the district « Camp des Boys», 68 for the district « Beau séjour » and 101 for the district Alibandeng. Mosquitoes were recorded by location and hours of capture and were sorted by genera. Anopheline mosquitoes were identified morphologically following the Gillies and Coetzee keys [28]. Culicinae were identified morphologically following the Edwards keys [29]. All mosquitoes were stored individually in numbered vials with desiccant and preserved at $-20^{\circ} \mathrm{C}$ until processing at the Medical Entomology Unit of the Institute for Biomedical research of the French Forces (IRBA), in Marseille (France).

\section{Laboratory mosquito processing}

Heads and thoraces of anopheline females were tested by enzyme-linked immunosorbent assay (ELISA) for 


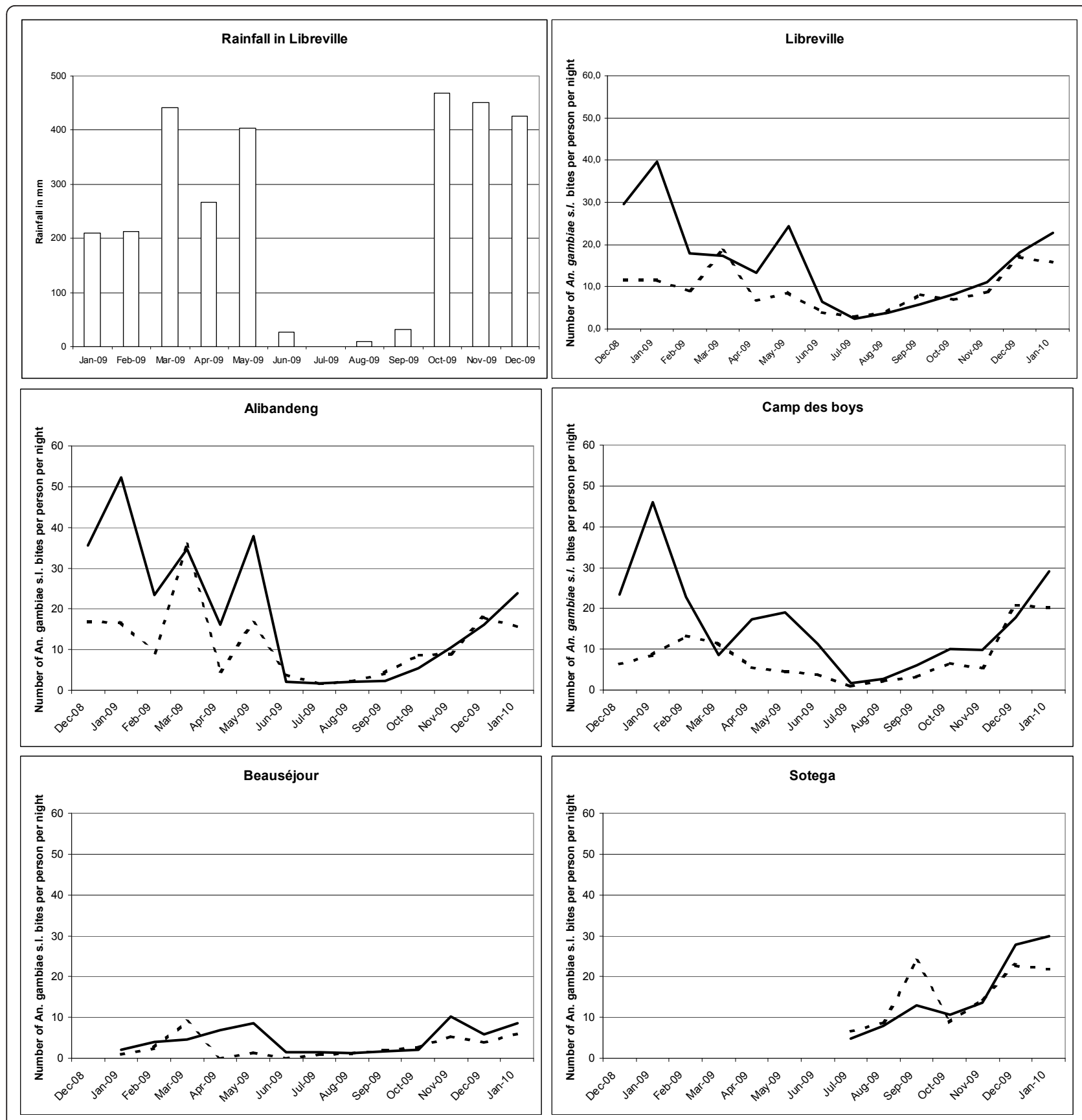

Figure 2 Number of An. gambiae s.l. bites per person per night indoors (dotted line) and outdoors (black line) from December 2008 to January 2010 in four quarters of Libreville according to the 2009 rainfall in Libreville.

P. falciparum circumsporozoite protein (CSP) [30]. In each site, a random sample of females belonging to the An. gambiae complex, together with all CSP-positive anopheline, were identified by polymerase chain reaction (PCR) at the species and molecular form levels [31]. Molecular characterizations of the $\mathrm{kdr}$ and ace1 mutations were carried out on these mosquitoes as previously described [32,33].

\section{Data analysis}

The human biting rate (HBR) was expressed as the number of female anopheline bites per human per night. Indoors, outdoors and global HBR were calculated. Values were averaged in order to calculate the HBR for the dry and the rainy season. The CSP index was calculated as the proportion of mosquitoes found to be positive for CSP. The entomological inoculation rate 
(EIR) was calculated as the product of the HBR and the CSP index of mosquitoes collected on humans. EIRs were calculated globally and by season (dry or rainy) for Libreville and for each district of study. The numbers of An. gambiae s.l. caught outdoors and indoors were standardized to calculate the endo-exophagic rates, then by district and by season. The CSP indices and the distribution of $\mathrm{kdr}$ alleles were compared using $\mathrm{Chi}^{2}$ test or Fisher's exact test.

\section{Results}

\section{Adult mosquito collection}

A total of 57,531 mosquitoes were caught during 341 person-nights of collection on human bait (161 personnights indoor and 180 person-nights outdoor). A total of 4,223 An. gambiae s.l. was collected (Table 1).

\section{Biting rates and biting behaviours of An. gambiae s.I}

Overall, the peak biting time was between 11:00 p.m. and 5:00 a.m. (Figure 3) with $89.1 \%$ of the bites occurring after 11:00 p.m. Human landing catches gave an average biting rate of 12.4 An. gambiae s.l. bites per person per night (14.5 outdoors; 9.9 indoors) for all Libreville. There were differences between the study areas: the average biting rate for An. gambiae s.l. ranged from four in Beauséjour (4.6 outdoors; 3.3 indoors) to 16 in Alibandeng (20.1 outdoors; 11.6 indoors). For the others districts (Akébé-Poteau, Camp des Boys and Sotega), the average biting rates were respectively of 9.3 (7.7 outdoors; 11 indoors), 12.7 (16.7 outdoors; 8.4 indoors) and 16 (15.8 outdoors; 16.2 indoors). The biting activity in Libreville and in its districts according to rainfall from December 2008 to January 2010 is shown in Figure 2. The aggressiveness of $A n$. gambiae s.l. differed also by season. During the rainy season, the average biting rate for An. gambiae s.l. was 15.5 bites per person per night, with a peak of 40 bites per person per night; this fell to 4.7 bites per person per night during the dry season. The differences of An. gambiae s.l. biting rates between districts persisted from the rainy to the dry season. For Alibandeng, Camp des Boys, Beauséjour and Sotega, the average biting rate fell respectively from 20.6 bites per person per night to 2.5 , from 15.8 to 4.3 , from 5.3 to 1.5 and from 19.5 to 10.8 . The density of the An. gambiae $s$. $l$. populations in the different areas was clearly linked to the level of rainfall. Each peak or decrease of rainfall was responsible for an increase or decrease in the population of $A n$. gambiae s.l., respectively, the following month.

Among the 4,223 An. gambiae s.l. caught, 2,622 (62.1\%) were caught outdoors, indicating that this species was globally more exophagic in Libreville. This was confirmed in three districts: Alibandeng (64.8\%), Camp des Boys (68.8\%) and Beauséjour (65.1\%). This was significantly different from the two other districts: Sotega (50.6\%) and Akébé-Poteau (44.6\%), where $A n$. gambiae s.l. seemed to be more endophagic (Chi ${ }^{2}$ test, $\mathrm{p}<10^{-7}$ ). Data on location (indoor vs outdoor) and by season of An. gambiae s.l. are presented in Figure 4, by district. An. gambiae s.l. seemed to modify its host seeking behaviour between the dry and the rainy season and was more endophagic during the dry season $(R R=1.71$ [1.45-2.02]), however, when analysed at the district level, this phenomenon is only seen in two districts: Alibandeng $(R R=2.39[1.44-3.99])$ and Sotega $(R R=1.47[1.19$ 1.82]).

\section{Molecular identification of An. gambiae s.l}

All specimens caught during the dry season along with a random sample of specimens caught during the rainy season were identified by PCR. Among the 1,006 specimens tested by PCR, the An. gambiae complex population was composed of 1,001 An. gambiae s.s. molecular form S (99.5\%), 3 An. melas (0.3\%) and 2 An. gambiae s.s. form M (0.2\%). Anopheles melas and An. gambiae molecular form $M$ were caught only during the rainy season: An. gambiae molecular form $\mathrm{M}$ was present only in Alibandeng and An. melas specimens were caught in Camp des Boys, Beauséjour and Sotega.

\section{CSP and EIR}

All 4,185 An. gambiae s.l. collected by human landing catches were processed by ELISA for P. falciparum antigen detection (467 from the dry season and 3,718 from the rainy season) and 33, all An. gambiae s.s. molecular form $S$, were found to be positive. CSP indexes and EIRs are presented in Table 2. As no statistically significant differences existed between the CSP indexes for the rainy and the dry season, an annual CSP index was calculated globally and for the four districts studied during both rainy and dry seasons, thus allowing the calculation of annual EIRs globally and by district. When the annual CSP indexes by district were compared, the annual CSP index in Alibandeng was statistically different from the others quarters but no difference was seen between Camp des Boys, Beauséjour and Sotega. An annual averaged CSP index and their respective annual EIRs were calculated for these three areas. The annual CSP index in Libreville was $0.78 \%$ [0.54-1.09]. The annual EIR was estimated at 33.9 infected bites per person per year (23.4 min and $47.3 \mathrm{max}$ ). Most malaria transmission occurred during the rainy season ( $87 \%$ of infected bites per person per year) but malaria transmission also occurred during the dry season from June to September. The level of transmission varied according to district: an inhabitant in Sotega receives about 88 infected bites per year, whereas an inhabitant in Alibandeng receives about 13 infected bites during the same period. 
Table 1 Distribution by genus and species of adult mosquitoes collected on humans in the studied areas of Libreville

\begin{tabular}{|c|c|c|c|c|c|c|c|c|c|c|c|c|}
\hline & \multicolumn{2}{|c|}{$\begin{array}{c}\text { Alibandeng } \\
101 \text { person-nights }\end{array}$} & \multicolumn{2}{|c|}{$\begin{array}{l}\text { Camp des Boys } \\
97 \text { person-nights }\end{array}$} & \multicolumn{2}{|c|}{$\begin{array}{c}\text { Beauséjour } \\
68 \text { person-nights }\end{array}$} & \multicolumn{2}{|c|}{$\begin{array}{c}\text { Sotega } \\
60 \text { person-nights }\end{array}$} & \multicolumn{2}{|c|}{$\begin{array}{l}\text { Akébé-Poteau } \\
15 \text { person-nights }\end{array}$} & \multicolumn{2}{|c|}{$\begin{array}{c}\text { Total } \\
341 \text { person-nights }\end{array}$} \\
\hline & $\begin{array}{c}\mathrm{N}^{\circ} \text { of } \\
\text { mosquitoes } \\
(\%)\end{array}$ & $\begin{array}{l}\mathrm{N}^{\circ} \text { of bites } \\
\text { per person } \\
\text { per night }\end{array}$ & $\begin{array}{c}\mathrm{N}^{\circ} \text { of } \\
\text { mosquitoes } \\
(\%)\end{array}$ & $\begin{array}{l}\mathrm{N}^{\circ} \text { of bites } \\
\text { per person } \\
\text { per night }\end{array}$ & $\begin{array}{c}\mathrm{N}^{\circ} \text { of } \\
\text { mosquitoes } \\
(\%)\end{array}$ & $\begin{array}{l}N^{\circ} \text { of bites } \\
\text { per person } \\
\text { per night }\end{array}$ & $\begin{array}{c}\mathrm{N}^{\circ} \text { of } \\
\text { mosquitoes } \\
(\%)\end{array}$ & $\begin{array}{l}N^{\circ} \text { of bites } \\
\text { per person } \\
\text { per night }\end{array}$ & $\begin{array}{c}\mathrm{N}^{\circ} \text { of } \\
\text { mosquitoes } \\
(\%)\end{array}$ & $\begin{array}{l}\mathrm{N}^{\circ} \text { of bites } \\
\text { per person } \\
\text { per night }\end{array}$ & $\begin{array}{c}\mathrm{N}^{\circ} \text { of } \\
\text { mosquitoes } \\
(\%)\end{array}$ & $\begin{array}{c}\mathrm{N}^{\circ} \text { of bites } \\
\text { per person } \\
\text { per night }\end{array}$ \\
\hline $\begin{array}{l}\text { Cx. } \\
\text { quinquefasciatus }\end{array}$ & $16862(88.3)$ & 166.9 & $14227(91.3)$ & 146.7 & 5001 (93.1) & 73.5 & $12352(91.7)$ & 205.9 & 3737 (93.2) & 249.1 & $52179(90.7)$ & 153.0 \\
\hline Mansonia sp & 339 (1.8) & 3.4 & $73(0.5)$ & 0.75 & $41(0.8)$ & 0.6 & $152(1.1)$ & 2.5 & $14(0.3)$ & 0.9 & 619 (1.1) & 1.8 \\
\hline $\begin{array}{l}\text { An. gambiae s. } \\
\text { I. }\end{array}$ & $1611(8.4)$ & 16 & $1236(7.9)$ & 12.7 & $275(5.1)$ & 4.0 & $962(7.1)$ & 16.0 & $139(3.5)$ & 9.3 & $4223(7.3)$ & 12,4 \\
\hline Ae. aegypti & $130(0.7)$ & 1.3 & $30(0.2)$ & 0.3 & $21(0.4)$ & 0.3 & \# & 0.0 & $110(2.7)$ & 7.3 & $291(0.5)$ & 0.9 \\
\hline Ae. albopictus & $146(0.8)$ & 1.4 & $22(0.1)$ & 0.2 & $32(0.6)$ & 0.5 & $8(0.1)$ & 0.1 & $11(0.3)$ & 0.7 & $219(0.4)$ & 0.6 \\
\hline Total & 19088 & 189 & 15588 & 160.7 & 5370 & 79.0 & 13474 & 224.6 & 4011 & 267.4 & 57531 & 168.7 \\
\hline
\end{tabular}




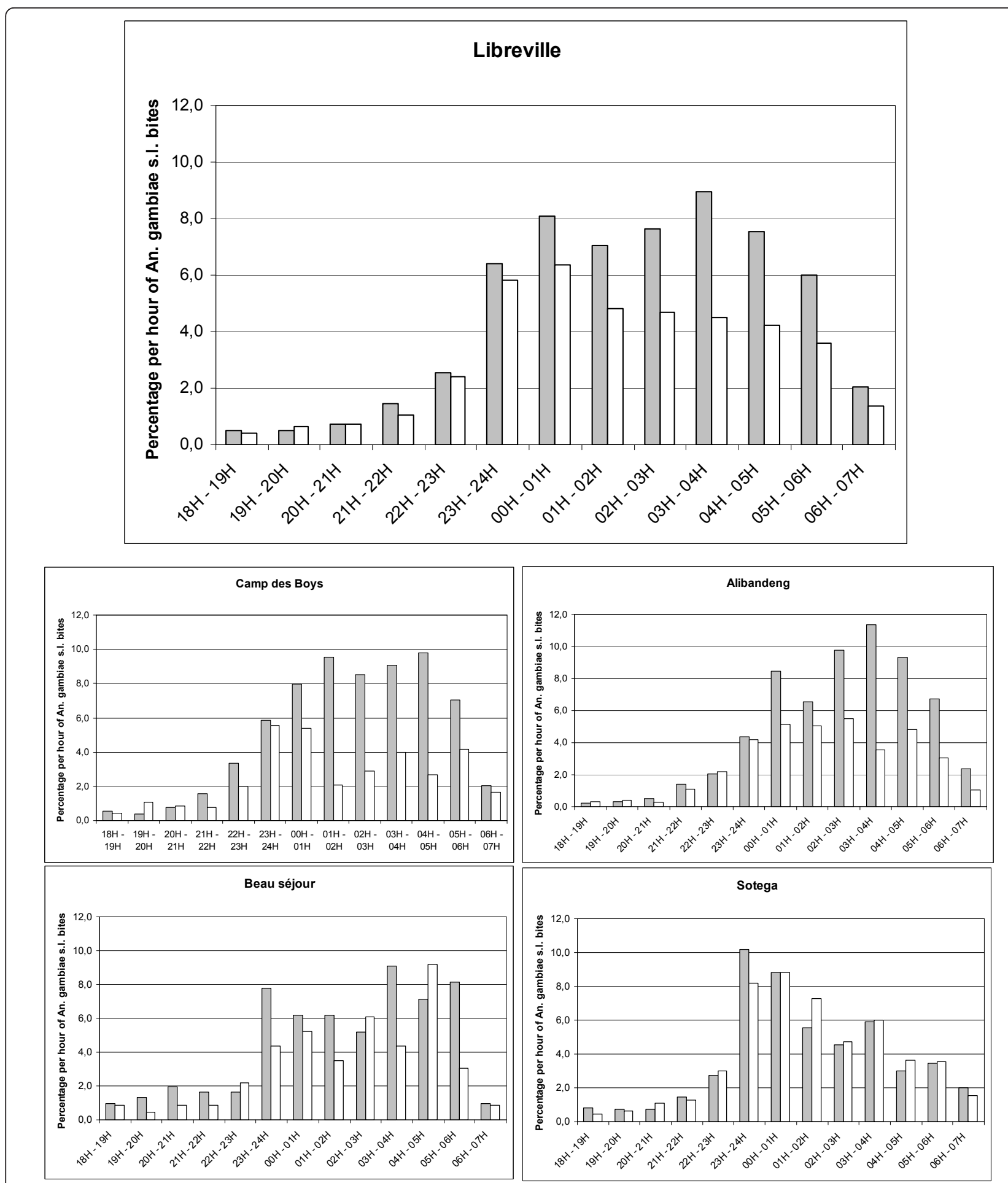

Figure 3 Hourly distribution of An. gambiae s.l. bites indoors (white bars) and outdoors (gray bars) in Libreville from December 2008 to January 2010 .

Kdr and ace1 mutation frequencies in An. gambiae s.I All CSP-positive mosquitoes per site and a random sample of at least 100 PCR-identified mosquitoes were tested for the $\mathrm{kdr}$ and ace1 mutations. The Ace 1 mutation was not identified in any of the 783 members of the $A n$. gambiae complex collected in the five areas of Libreville (163 in Alibandeng, 209 in Camp des Boys, 121 in Beauséjour, 186 in Sotega and 104 in Akébé- 


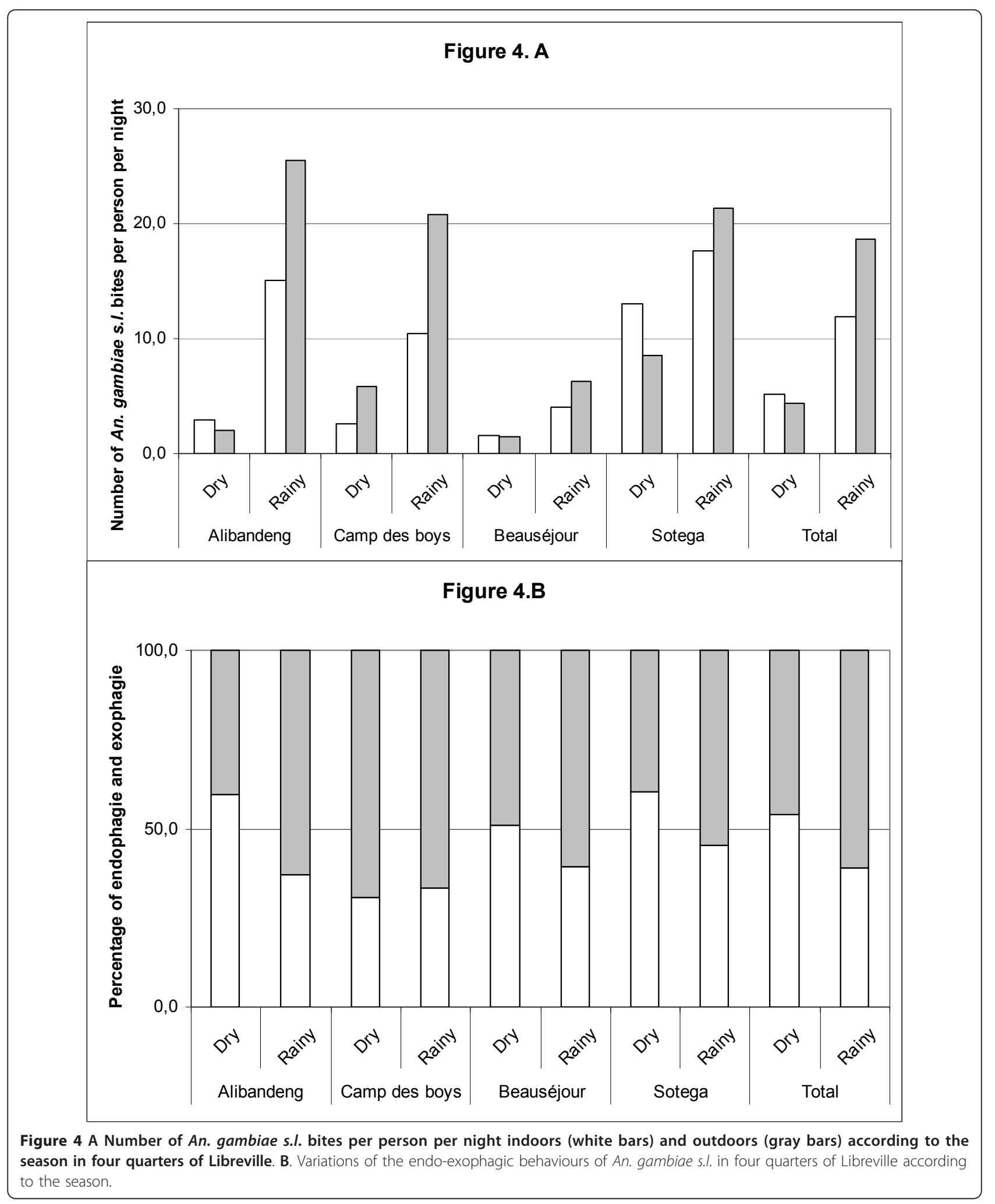

Poteau). A total of 1020 An. gambiae molecular form S were tested for the detection of pyrethroid knock-down resistance. Both kdr-e and kdr-w resistance alleles were present with a higher frequency for kdr-w allele (76.0\%) than kdr-e allele (23.5\%). The genotypic and the allelic frequencies are shown in Table 3 . The comparison of 
Table 2 Mean daily human biting rate (HBR) during the dry and the rainy season; dry, rainy and annual CSP indices; dry, rainy and annual entomological inoculation rates (EIR) of An. gambiae s.I. by sites in Libreville: data collected from December 2008 to January 2010

\begin{tabular}{|c|c|c|c|c|c|c|c|c|c|c|c|c|c|c|c|}
\hline & \multicolumn{5}{|c|}{ Dry season } & \multicolumn{5}{|c|}{ Rainy season } & \multicolumn{5}{|c|}{ All year } \\
\hline & $\begin{array}{c}\text { Total } \\
\text { collected }\end{array}$ & HBR & $\begin{array}{l}\text { Tested } \\
\text { for CSP }\end{array}$ & $\begin{array}{l}\text { CSP rate } \\
{[95 \% \text { C.I] }}\end{array}$ & $\begin{array}{l}\text { Dry } \\
\text { season } \\
\text { EIR }\end{array}$ & $\begin{array}{c}\text { Total } \\
\text { collected }\end{array}$ & HBR & $\begin{array}{l}\text { Tested } \\
\text { for CSP }\end{array}$ & $\begin{array}{l}\text { CSP rate } \\
{[95 \% \text { C.I] }}\end{array}$ & $\begin{array}{c}\text { Rainy } \\
\text { season EIR }\end{array}$ & $\begin{array}{l}\text { Dry CSP/ } \\
\text { Rainy CSP }\end{array}$ & $\begin{array}{l}\text { Annual } \\
\text { CSP }\end{array}$ & $\begin{array}{c}\text { Annual } \\
\text { EIR }\end{array}$ & $\begin{array}{c}\text { Annual } \\
\text { averaged } \\
\text { CSP* }\end{array}$ & $\begin{array}{c}\text { Annual } \\
\text { averaged EIR }\end{array}$ \\
\hline Alibandeng & 65 & 2.5 & 65 & $\begin{array}{c}0 \\
{[0.0 ; 5.5]}\end{array}$ & 0.0 & 1546 & 20.6 & 1526 & $\begin{array}{c}0.26 \\
{[0.07 ; 0.67]}\end{array}$ & 2.5 & NS & $\begin{array}{c}0.25 \\
{[0.06 ; 0.64]}\end{array}$ & 13.3 & - & - \\
\hline $\begin{array}{l}\text { Camp des } \\
\text { Boys }\end{array}$ & 109 & 4.3 & 108 & $\begin{array}{c}0.93 \\
{[0.02 ; 5.05]}\end{array}$ & 4.7 & 1127 & 15.8 & 1113 & $\begin{array}{c}0.89 \\
{[0.43 ; 1.64]}\end{array}$ & 34.5 & NS & $\begin{array}{c}0.9 \\
{[0.45 ; 1.60]}\end{array}$ & 39.2 & 1.11 & 48.4 \\
\hline Beauséjour & 35 & 1.5 & 35 & $\begin{array}{c}0 \\
{[0.0 ; 10.0]} \\
\end{array}$ & 0.0 & 240 & 5.3 & 239 & $\begin{array}{c}0.84 \\
{[0.10 ; 2.89]} \\
\end{array}$ & 9.3 & NS & $\begin{array}{c}0.72 \\
{[0.08 ; 2.61]} \\
\end{array}$ & 10.6 & 1.11 & 16.3 \\
\hline Sotega & 260 & 10.8 & 259 & $\begin{array}{c}1.16 \\
{[0.23 ; 3.34]}\end{array}$ & 19.2 & 702 & 19.5 & 701 & $\begin{array}{c}1.57 \\
{[0.78 ; 5.1]}\end{array}$ & 68.7 & NS & $\begin{array}{c}1.45 \\
{[0.79 ; 2.43]}\end{array}$ & 87.9 & 1.11 & 67.3 \\
\hline $\begin{array}{l}\text { Akébé- } \\
\text { Poteau }\end{array}$ & - & - & - & - & - & 139 & 9.2 & 139 & $\begin{array}{c}1.43 \\
{[0.17 ; 5.1]}\end{array}$ & 31.9 & - & $\begin{array}{c}1.43 \\
{[0.17 ; 5.1]}\end{array}$ & - & - & - \\
\hline Total & 469 & 4.7 & 467 & $\begin{array}{c}0.85 \\
{[0.23 ; 2.17]}\end{array}$ & 4.5 & 3754 & 15.5 & 3718 & $\begin{array}{c}0.78 \\
{[0.52 ; 1.11]}\end{array}$ & 29.4 & NS & $\begin{array}{c}0.78 \\
{[0.54 ; 1.09]}\end{array}$ & 33.9 & - & - \\
\hline
\end{tabular}

*Annual CSP indexes of the four areas studied during the two seasons have been compared using Chi ${ }^{2}$ test. Only the Annual CSP index of Alibandeng was statistically different of the others. An annual averaged CSP index has been calculated for the three remaining areas. 
Table 3 Distribution of the genotypic and allelic frequencies of the kdr loci of An.gambiae S.S. molecular form S in the studied areas of Libreville

\begin{tabular}{|c|c|c|c|c|c|c|c|c|c|c|c|}
\hline & \multirow[b]{2}{*}{$\mathrm{N}^{\circ}$ of specimens } & \multicolumn{5}{|c|}{ Genotypic frequencies } & \multicolumn{5}{|c|}{ Allelic frequencies } \\
\hline & & $\operatorname{ReS}$ & $\operatorname{ReRe}$ & ReRw & RwRw & RwS & SS & $\operatorname{Re}$ & $\mathrm{Rw}$ & $S$ & $p^{*}$ \\
\hline Alibandeng & 240 & $1(0.4)$ & $13(5.4)$ & $80(33.3)$ & $146(60.9)$ & - & - & 22.3 & 77.5 & 0.2 & \\
\hline Camp des boys & 310 & - & $18(5.8)$ & $120(38.7)$ & $168(54.2)$ & $2(0.6)$ & $2(0.6)$ & 25.1 & 73.9 & 1 & \\
\hline Beauéjour & 138 & - & $7(5.1)$ & $48(34.8)$ & $82(54.4)$ & - & $1(0.7)$ & 22.5 & 76.8 & 0.7 & NS \\
\hline Sotega & 203 & - & $15(7.4)$ & $63(31.0)$ & $124(61.1)$ & - & $1(0.5)$ & 22.9 & 76.6 & 0.5 & \\
\hline Akébé Poteau & 129 & - & $8(6.2)$ & $44(34.1)$ & $77(59.7)$ & - & - & 23.3 & 76.7 & 0 & \\
\hline Libreville-Total & 1020 & $1(0.1)$ & $61(6.0)$ & $355(34.8)$ & $597(58.5)$ & $2(0.2)$ & $4(0.4)$ & 23.5 & 76.0 & 0.5 & \\
\hline
\end{tabular}

$p^{*}$ the allelic frequencies of the kdr loci are not different between the different districts of Libreville

the allelic frequencies showed no difference between districts.

\section{Malaria in patients consulting for fever}

From December 2008 to January 2010, 1,730 children (under 15 years old) of both sexes consulted for fever: 419 of them (24.2\%) were infected by P. falciparum. The ratio of infected patients is described in Figure 5. The proportion of infected patients is higher in the last months of the rainy season and dropped during the dry season only to increase again with the start of the rainy season.

\section{Discussion}

The nocturnal mosquito biting rate was intense essentially due to Culex quinquefasciatus in both areas of Libreville but varied according to the location in the city. The Cx. quinquefasciatus aggressiveness ranged from 73 bites per night in Beauséjour to 250 bites per night in Akébé-Poteau. The densities of $C x$. quinquefasciatus were higher in the centre of the city in the most urbanized areas, suggesting difficulties in waste management, and were lower in the peripheral areas of Alibandeng and Camp des Boys. Stegomya spp. population densities were low during the survey, but night captures

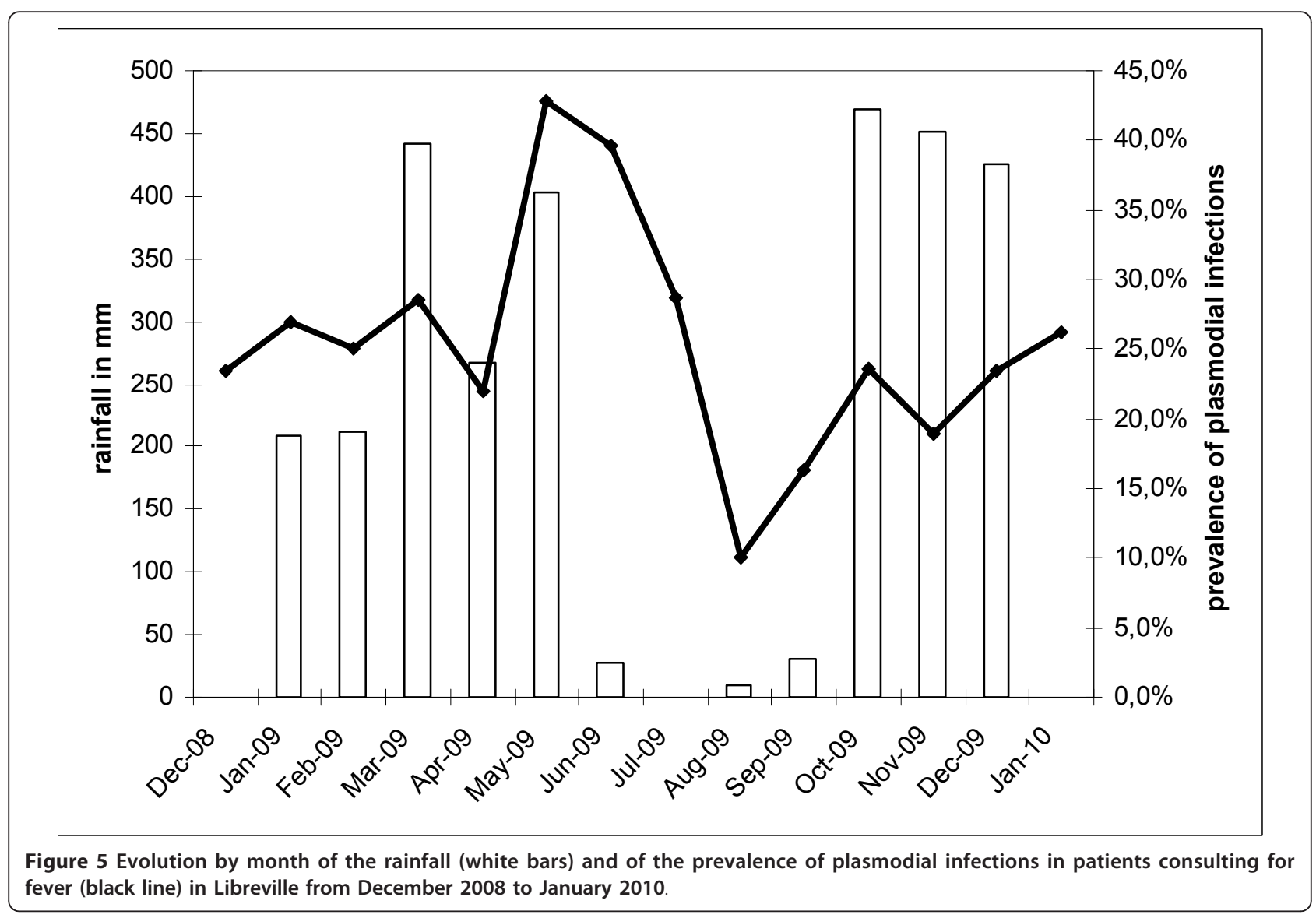


are not appropriate for such diurnal species. The abundance of Aedes aegypti and Aedes albopictus seemed to vary according to the districts signifying that the risk of chikungunya or dengue transmission is probably not homogenous throughout Libreville. In Akébé-Poteau, a more urbanized area with less vegetation, Ae. aegypti was more present than Ae. albopictus. In the others districts, where gardens and other green areas are more important the two species were caught with equal frequency.

Three members of the An. gambiae complex were present in Libreville: An. melas, An. gambiae s.s. molecular form $\mathrm{M}$ and $A n$. gambiae s.s. molecular form S. The presence of An. melas and An. gambiae s.s. molecular form M was recorded for the first time in Libreville. Only An. gambiae s.s. molecular form $\mathrm{S}$, that represented more than 99\% of the anopheline population, was involved in malaria transmission, which is contrary to what is observed in Port Gentil, the second main city of the country, where An. melas is an important malaria vector [22]. The level of transmission varied between the districts and the annual EIR ranged from 13 to 87 P. falciparum infected bites per person per year. Differences between districts can be explained in part by the variations in An. gambiae s.s. molecular form $\mathrm{S}$ biting rates for three of the districts however, in Alibandeng, where the annual aggressiveness was one of the highest, the lower level of transmission is possibly due to a low CSP index and to a higher exophagic behaviour of An. gambiae s.l..

A meta-analysis of studies of malaria transmission in sub-Saharan Africa found a linear negative relationship between the level of malaria transmission and the level of urbanization: transmission decreased from rural to periurban areas and from peri-urban areas to urban centre [34] and these findings have been confirmed in the field [35]. In Libreville, the situation appears different as the highest EIR was in the most central and urbanized area and the lowest in a peripheral area. In urban settings, malaria risk heterogeneity is due to diversity in degrees and types of urbanization, density of human population, quality of water and waste management, vector control measures, household factors and access to health care $[7,14,34,36,37]$ or human migration patterns which could import parasites from rural areas [38-40]. The occurrence of malaria in African cities has been linked to agricultural practices [5,41-45], distance from breeding sites [46-50] and vegetation cover [50]. In Libreville, some of these factors could explain the differences between the intermediate area (Beauséjour), the peripheral area (Alibandeng) and the central zone (Sotega) and the apparent inversion of the usual gradient of transmission from periurban areas to urban centre. Households with low socioeconomic status and poor housing conditions have already been identified as risk factors for urban malaria.
In the central area, districts like Sotega which have slumlike conditions characterized by a high density of population, a low socio-economic level and difficulties in waste management, as seen by the high biting rate of $C x$ quinquefasciatus. Contrary to the usual scheme described in most of African cities, the peripheral and intermediate areas are more affluent, less densely populated and inhabitants have a higher socio economic status than those of the central area of Sotega. The gradient of transmission described from peri-urbans areas to urban centre is probably more dependent of the socio-economic status of the area than of the location within a city. Urban malaria control programmes thus need to consider living conditions in a given area rather than the location in a city to determine areas favourable to malaria transmission. In 2007, a preliminary study conducted in the French military camp showed a low transmission of malaria in Libreville [22]. However, the authors identified two limitations: first, a single study in one area is not sufficient to assess the global level of transmission and second, that the vector control programme implemented in the camp all year around could have minimized the level of malaria transmission. This current study included the district Camp des Boys due to its proximity to the French military camp of Libreville, and found that the level of transmission was ten fold higher with a measured annual EIR of 39.2 infected bites per person per year vs. the estimated annual EIR of 3.7 infected bites per person per year in the French military camp. It is the first study showing the effectiveness of the vector control programme implemented against malaria vectors in the French camps in Africa [24].

This study also showed that most of malaria transmission occurred during the rainy season. As the CSP indexes were not statistically different between the rainy and the dry seasons, this variation is due to the climatic conditions that are more favourable to An. gambiae s.l. populations during the rainy period. Rainfalls provide larvae breeding sites, allowing an increase in the density of the populations and a higher level of hygrometry increases the longevity of the populations and therefore their vector capacity. The predominant presence of $S$ form is further evidence of the importance of rain-dependent temporary breeding sites in Libreville [51].

The evolution of the proportion of $P$. falciparum infected persons in patients consulting for fever is proof of the link between malaria transmission and rainfall. However, many people spend their summer holidays in the inlands, and the increase of malaria transmission seen in October after the return of people could be explained by the importation of $P$. falciparum to the city by returning vacationers and students [38-40]. Preliminary work conducted in 2007 showed that the aggressiveness of An. gambiae s.l. was linked to rainfall; this 
study showed that malaria transmission in Libreville is clearly linked to rainfall. Malaria transmission primarily occurred during the rainy season, but transmission persisted during the dry season, though it was six times lower (4.5 infected bites per person during the dry season vs. 29.5 infected bites per person during the rainy season).

As An. gambiae s.l. have been caught both indoors and outdoors, malaria transmission can occur both indoors and outdoors. During the dry season, An. gambiae s.l. seemed to modify its host-seeking behaviour and to penetrate more easily in the houses. This modification of the biting behaviour could participate to the maintenance of malaria transmission during the dry season. Considering the four districts followed during the two seasons, An. gambiae s.l. was endophagic in one of them (Sotega). Interestingly, malaria transmission was higher in this district during the dry season.

The human night biting pattern supports the efficacy of impregnated nets in malaria prevention. Nevertheless, some biting activity takes place at the end of night (14\% of bites from 5:00 to 7:00 a.m.) when people don't use any protection. As recommended by WHO, repellents are used by French forces stationed in sub-Saharan countries to complete protection, outside of the period of use of mosquito nets even in the early morning [5,52-54]. A successful trial in Amazonia has showed the efficiency of this strategy using a "natural" locally produced repellent [55]. However, plant extracts have limited protection, for a short duration "natural" repellents traditionally used in Africa can be proposed [56-58].

As previously described, in Libreville, both $\mathrm{kdr}-\mathrm{w}$ and kdr-e mutations in An. gambiae molecular form $\mathrm{S}$ were present [23,59] with a higher frequency of the kdr-w allele $(76 \%)$ than the $k d r$-e allele $(23.5 \%)$ as reported in neighbouring countries [59-62]. As those mutations have been tightly linked with resistant phenotypes, the effectiveness of the current distribution programme of pyrethroid-impregnated bed nets in Libreville has to be assessed however none consensus has been reached on the impact of kdr mutations on the efficacy of ITNs [63-69]. No insensitive AChE mutations were found in the five districts, suggesting that the molecular resistance to organophosphates and carbamates insecticides in $A n$. gambiae s.s. form $\mathrm{S}$ has not infiltrated Libreville and that these compounds are still a viable alternative.

\section{Conclusions}

Malaria transmission in Libreville remains high and seems to be very heterogeneous throughout the city. New studies, such as entomologic surveys and human surveys, are needed to better understand the factors of this heterogeneity. As an uncontrolled use of carbamates or organophosphates could probably lead to select multi- resistant specimens, the use of molecular markers has to be developed in Gabon as a routine tool for malaria control programme deciders, as well as the use of standardized bio-essays - to take into account the possible involvement of additional resistance mechanisms-, as it has begun in the neighbouring countries [70-72].

\section{Acknowledgements}

We thank the collector's team for commitment in the fieldwork.

This study was supported by Délégation Générale pour l'Armement (France).

\section{Author details}

'Département de Parasitologie-mycologie, Faculté de médecine, Université des Sciences de la Santé, B.P. 4009, Libreville, Gabon. '2UMR 6236, Unité d'entomologie médicale, IRBA antenne Marseille, GSBDD Marseille Aubagne, 111 avenue de la corse BP 40026, 13568 Marseille Cedex 2, France.

\section{Authors' contributions}

JRM was responsible for the supervision of data collection, analysis, interpretation and production of the final manuscript and revisions. TC contributed to the supervision of data collection, the data analysis, and interpretation. FJ contributed to the supervision of data collection, to the data analysis. CC contributed to the data analysis and production of final manuscript. EP contributed to the data analysis. LG contributed to the data analysis. MK contributed to overall scientific management, analysis, interpretation and preparation of the final manuscript and revisions. FP was responsible for overall scientific management, analysis, interpretation and preparation of the final manuscript and revisions. All authors read and approved the final manuscript.

\section{Competing interests}

The authors declare that they have no competing interests.

Received: 21 October 2011 Accepted: 9 February 2012

Published: 9 February 2012

\section{References}

1. Donnelly MJ, McCall PJ, Lengeler C, Bates I, D'Alessandro U, Barnish G, Konradsen F, Klinkenberg E, Townson H, Trape JF, Hastings IM, Mutero C: Malaria and urbanization in sub-Saharan Africa. Malar J 2005, 4:12.

2. Matthys B, Vounatsou P, Raso G, Tschannen AB, Becket EG, Gosoniu L, Cissé G, Tanner M, N'goran EK, Utzinger J: Urban farming and malaria risk factors in a medium sized town in Côte d'Ivoire. AmJTrop Med Hyg 2006, 75:1223-1235.

3. Girod R, Orlandi-Pradines E, Rogier C, Pagès F: Malaria transmission and insecticide resistance of Anopheles gambia (Diptera: Culicidae) in the French military camp of Port-Bouet, Abidjan (Côte d'Ivoire): implications for vector control. J Med Entomol 2006, 43:1082-1087.

4. Pagès F, Orlandi-Pradines $E$, Corbel V: Vectors of malaria: biology, diversity, prevention, and individual protection. Med Mal Infect 2007, 37:153-161.

5. Klinkenberg E, McCall PJ, Wilson MD, Akoto AO, Amerasinghe FP, Bates I, Verhoeff FH, Barnish G, Donnelly MJ: Urban malaria and anaemia in children: a cross-sectional survey in two cities of Ghana. Trop Med Int Health 2006, 11:578-588.

6. Keiser J, Utzinger J, Caldas de Castro M, Smith TA, Tanner M, Singer BH: Urbanization in sub-Saharan Africa and implications for malaria control. Am J Trop Med Hyg 2004, 71(suppl 2):118-127.

7. Hay SI, Guerra CA, Tatem AJ, Atkinson PM, Snow RW: Urbanization, malaria transmission and disease burden in Africa. Nat Rev Microbio/ 2005, 3:81-90.

8. Wang SJ, Lengeler C, Smith TA, Vounatsou P, Cisse G, Diallo DA, Akogbeto M, Matsiwa D, Teklehaimanot A, Tanner M: Rapid urban malaria appraisal (RUMA) in sub-Saharan Africa. Malar J 2005, 4:40.

9. Wang SJ, Lengeler C, Smith TA, Vounatsou P, Diadie DA, Pritroipa X, Conelbo N, Kientga M, Tanner M: Rapid urban malaria appraisal (RUMA) I: Epidemiology of urban malaria in Ouagadougou. Malar J 2005, 4:43.

10. Wang SJ, Lengeler C, Mtasiwa D, Mshana T, Manane L, Maro G, Tanner M: Rapid urban malaria appraisal (RUMA) II: Epidemiology of malaria in Dar es Salaam (Tanzania). Malar J 2006, 5:29. 
11. Wang SJ, Lengeler C, Smith TA, Vounatsou P, Akogbeto M, Tanner M: Rapid urban malaria appraisal (RUMA) IV: Epidemiology of urban malaria in Cotonou (Bénin). Malar J 2006, 5:45.

12. Davis JC, Clark TD, Kemble SK, Talemwa N, Njama-Meya D, Staedke SG, Dorsey G: Longitudinal study of urban malaria in a cohort of Ugandan children: description of study site, census and recruitment. Malar J 2006, 5:18

13. Othnigué $N$, Wyss $K$, Tanner $M$, Genton B: Urban malaria in the sahel: prevalence and seasonality of presumptive malaria and parasitaemia at primary care level in Chad. Trop Med Int Health 2006, 11:204-210.

14. Antonio-kondjio C, Simard F, Awono-Ambene P, Ngassam P, Toto JC, Tchuinkam T, Fontenille D: Malaria vectors and urbanization in the equatorial forest region of south Cameroon. Trans R Soc Trop Med Hyg 2005, 99:347-354.

15. Omumbo JA, Guerra CA, Hay SI, Snow RW: The influence of urbanisation on measures of Plasmodium falciparu infection prevalence in east Africa. Acta Trop 2005, 93:11-21

16. Journal officiel de la République Gabonaise de février 2005; №2.

17. Dzeing-Ella A, Nze Obiang PC, Tchoua R, Planche T, Mboza B, Mbounja M, Muller-Roemer U, Jarvis J, Kendjo E, Ngou-Milama E, Kremsner PG, Krishna S, Kombila M: Severe falciparum malaria in Gabonese children: clinical and laboratory features. Malar J 2005, 4:1.

18. Issifou S, Kendjo E, Missinou MA, Matsiegui PB, Dzeing-Ella A, Dissanami FA, Kombila M, Krishna S, Kremsner PG: Differences in presentation of severe malaria in urban and rural Gabon. AmJTrop Med Hyg 2007, 77:1015-1019.

19. Sylla EH, Kun JF, Kremsner PG: Mosquito distribution and entomological inoculation rates in three malaria-endemic areas in Gabon. Trans $R$ Soc Trop Med Hyg 2000, 94:652-656.

20. Elissa N, Migot-Nabias F, Luty A, Renaut A, Touré F, Vaillant M, Lawoko M, Yangari P, Mayombo J, Lekoulou F, Tshipamba P, Moukagni R, Millet P, Deloron P: Relationship between entomological inoculation rate, Plasmodium falciparu prevalence rate, and incidence of malaria attack in rural Gabon. Acta Trop 2003, 85:355-361.

21. Elissa N, Karch S, Bureau P, Ollomo B, Lawoko M, Yangari P, Ebang B, Georges AJ: Malaria transmission in a region of savanna-forest mosaic, Haut-Ogooué, Gabon. J Am Mosa Control Assoc 1999, 15:15-23.

22. Mourou JR, Coffinet T, Jarjaval F, Pradines B, Amalvict R, Rogier C, Kombila M, Pagès F: Malaria transmission and insecticide resistance of Anopheles gambia in Libreville and Port-Gentil, Gabon. Malar J 2010, 9:321.

23. Pinto J, Lynd A, Elissa N, Donnelly MJ, Costa C, Gentile G, Caccone A, Do Rosario VE: Co-occurrence of East and West kdr mutations suggests high levels of resistance to pyrethroid insecticides in Anopheles gambia from Libreville, Gabon. Med Vet Entomol 2006, 20:27-32.

24. Pagès F, Peyrefitte CN, Toungve $M$, Jarjaval F, Brisse $S$, Iteman I, Gravier $P$, Nkoghe D, Grandadam M: Aedes albopictu mosquito: the main vector of the 2007 Chikungunya outbreak in Gabon. PLoS One 2009, 4:e4691.

25. Bouyou-Akotet MK, Mawili-Mboumba DP, Kendjo E, Mabika-Mamfoumbi M, Brice Ngoungou E, Dzeing-Ella A, Pemba-Mihindou M, Ibinga E, EfameEya E, MCRU team, Planche T, Kremsner PG, Kombila M: Evidence of decline of malaria in the general hospital of Libreville, Gabon from 2000 to 2008. Malar J 2009, 8:300.

26. Bouyou-Akotet MK, Nzenze-Afene S, Ngoungou EB, Kendjo E, OwonoMedang M, Lekana-Douki JB, Obono-Obiang G, Mounanga M, Kombila M: Burden of malaria during pregnancy at the time of IPTp/SP implementation in Gabon. AmJ Trop Med Hyg 2010, 82:202-209.

27. Ramharter M, Schuster K, Bouyou-Akotet MK, Adegnika AA, Schmits K, Mombo-Ngoma G, Agnandji ST, Nemeth J, Nzenze Afène S, Issifou S, Ndombi Onnas I, Kombila M, Kremsner PG: Malaria in pregnancy before and after the implementation of a National IPTp program in Gabon. AmJTrop Med Hyg 2007, 77:418-422.

28. Gillies MT, Coetzee M: A supplement to the anophelinae of Africa south of the Sahara (Afrotropical region). 55 edition. Johannesburg, South Africa: The South African Institut for Medical Research; 1987.

29. Edwards FW: Mosquitoes of the Ethiopian Region. III.- Culicine adults and pupae London: British Museum (Natural History); 1941.

30. Burkot TR, Zavala F, Gwadz RW, Collins FH, Nussenzweig RS, Roberts DR: Identification of malaria infected mosquitoes by a two-site enzymelinked immunosorbent assay. AmJTrop Med Hyg 1984, 33:227-231.

31. Fanello C, Santolamazza F, Della Torre A: Simultaneous identification of species and molecular forms of the Anopheles gambia complex by PCRRFLP. Med Vet Entomol 2002, 16:461-464.
32. Bass C, Nikou D, Donnelly MJ, Williamson MS, Ranson H, Ball A, Vontas J, Field LM: Detection of knockdown resistance (kdr) mutations in Anopheles gambia: a comparison of two new high-throughput assays with existing methods. Malar J 2007, 6:111.

33. Weill M, Malcolm C, Chandre F, Mogensen K, Berthomieu A, Marquine M, Raymond $\mathrm{M}$ : The unique mutation in ace-1 giving high insecticide resistance is easily detectable in mosquito vectors. Insect Mol Biol 2004, 3:1-7.

34. Robert V, Macintyre K, Keating J, Trape JF, Duchemin JB, Warren M, Beier JC Malaria transmission in urban subsaharan Africa. AmJTrop Med Hyg 2003, 68:169-176.

35. Thwing Jl, Mihigo J, Fernandes AP, Saute F, Ferreira C, Fortes F, de Oliveira AM, Newman RD: How much malaria occurs in urban Luanda, Angola? A health facility-based assessment. AmJTrop Med Hyg 2009, 80:487-491,

36. Khaemba BM, Mutant A, Bett MK: Studies of anopheline mosquitoes transmitting malaria in a newly developed high-land urban area: a case study of Moi University and its environs. East Afr Med 1994, 71:159-164.

37. Baragatti M, Fournet F, Henry MC, Assi S, Ouedraogo H, Rogier C, Salem G: Social and environmental malaria risk factors in urban areas of Ouagadougou. Burkina Faso Malar J 2009, 8:13.

38. Bogreau H, Renaud F, Bouchiba H, Durand P, Assi SB, Henry MC, Garnotel E, Pradines B, Fusai T, Wade B, Adehossi E, Parola P, Kamil MA, Puijalon O, Rogier C: Genetic diversity and structure of African Plasmodium falciparu populations in urban and rural areas. AmJTrop Med Hyg 2006, 74:953-959.

39. Rakotomanana F, Ratovonjato J, Randremanana RV, Randrianasolo L, Raherinjafy R, Rudant JP, Richard V: Geographical and environmental approaches to urban malaria in Antananarivo (Madagascar). BMC Infect Dis 2010, 10:173.

40. Siri JG, Wilson ML, Murray S, Rosen DH, Vulule JM, Slutsker L, Lindblade KA: Significance of travel to rural areas as a risk factor for malarial anemia in an urban setting. AmJTrop Med Hyg 2010, 82:391-397.

41. Afrane YA, Klinkenberg E, Drechsel P, Owusu-Daaku K, Garms R, Kruppa T: Does irrigated urban agriculture influence the transmission of malaria in the city of Kumasi, Ghana? Acta Trop 2004, 89:125-134.

42. Matthys B, N'Goran EK, Kone M, Koudou BG, Vounatsou P, Cisse G, Tschannen AB, Tanner M, Utzinger J: Urban agricultural land use and characterization of mosquito larval habitats in a medium-sized town of Cote d'Ivoire. J Vector Ecol 2006, 31:319-333.

43. Klinkenberg E, McCall PJ, Hastings IM, Wilson MD, Amerasinghe FP, Donnelly MJ: Malaria and irrigated crops, Accra, Ghana. Emerg Infect Dis 2005, 11:1290-1293.

44. Robert V, Awono-Ambene P, Thioulouse J: Ecology of larval mosquitoes, with special reference to Anopheles arabiensi (Diptera: Culcidae) in market-garden wells in urban Dakar, Senegal. J Med Entomol 1998, 35:948-955.

45. Klinkenberg E, McCall P, Wilson MD, Amerasinghe FP, Donnelly MJ: Impact of urban agriculture on malaria vectors in Accra, Ghana. Malar J 2008 7:151.

46. Stoler J, Weeks JR, Getis A, Hill AG: Distance threshold for the effect of urban agriculture on elevated self-reported malaria prevalence in Accra, Ghana. AmJTrop Med Hyg 2009, 80:547-54.

47. Staedke SG, Nottingham EW, Cox J, Kamya MR, Rosenthal PJ, Dorsey G: Short report: proximity to mosquito breeding sites as a risk factor for clinical malaria episodes in an urban cohort of Ugandan children. AmJTrop Med Hyg 2003, 69:244-246.

48. Trape JF, Lefebvre-Zante E, Legros F, Ndiaye G, Bouganali H, Druilhe $P$, Salem G: Vector density gradients and the epidemiology of urban malaria in Dakar, Senegal. AmJTrop Med Hyg 1992, 47:181-189.

49. Robert V, Le Goff G, Toto JC, Mulder L, Fondjo E, Manga L, Carnevale P: Anthropophilic mosquitoes and malaria transmission at Edea, Cameroon. Trop Med Parasitol 1993, 44:14-18.

50. Peterson I, Borrell LN, El-Sadr W, Teklehaimanot A: A temporal-spatial analysis of malaria transmission in Adama, Ethiopia. AmJTrop Med Hyg 2009, 81:944-949.

51. Touré YT, Petrarca V, Traore SF, Coulibaly A, Maiga HM, Sankaré O, Sow M, Di Deco MA, Coluzzi M: The distribution and inversion polymorphism of chromosomally recognized taxa of the Anopheles gambia complex in Mali, West Africa. Parassitologia 1998, 40:477-511.

52. Orlandi-Pradines E, Rogier C, Koffi B, Jarjaval F, Bell M, Machault V, Pons C, Girod R, Boutin JP, Pagès $F$ : Major variations in malaria exposure of 
travellers in rural areas: an entomological cohort study in western Côte d'Ivoire. Malar J 2009, 8:171.

53. Pagès F, Texier G, Pradines B, Gadiag L, Machault V, Jarjaval F, Penhoat K, Berger F, Trape JF, Rogier C, Sokhna C: Malaria transmission in Dakar: a two-year survey. Malar J 2008, 7:178.

54. Organisation mondiale de la santé-comité d'experts du paludisme $18^{\circ}$ rapport. Série des rapports techniques 735. Ed OMS Genève 1986, 118.

55. Hill N, Lenglet A, Arnéz AM, Carneiro I: Plant based insect repellent and insecticide treated bed nets to protect against malaria in areas of early evening biting vectors: double blind randomised placebo controlled clinical trial in the Bolivian Amazon. BMJ 2007, 335:1023-1026.

56. Konan YL, Sylla MS, Doannio JM, Traoré S: Comparison of the effect of two excipients (karite nut butter and vaseline) on the efficacy of Cocos nucifer, Elaeis guineensi and Carapa procer oil-based repellents formulations against mosquitoes biting in Ivory Coast. Parasite 2003, 10:181-184.

57. Odalo JO, Omolo MO, Malebo H, Angira J, Njeru PM, Ndiege IO, Hassanali A: Repellency of essential oils of some plants from the Kenyan coast against Anopheles gambia. Acta Trop 2005, 95:210-218.

58. PPAV Working Groups: Personal protection against biting insects and ticks. Parasite 2011, 18:93-111.

59. Santolamazza F, Calzetta M, Etang J, Barrese E, Dia I, Caccone A, Donnelly MJ, Petrarca V, Simard F, Pinto J, Della Torre A: Distribution of knock-down resistance mutations in Anopheles gambia molecular forms in west and west-central Africa. Malar J 2008, 7:74.

60. Etang J, Fonjo E, Chandre F, Morlais I, Brengues C, Nwane P, Chouaibou M, Ndjemai H, Simard F: Short report: First report of knockdown mutations in the malaria vector Anopheles gambia from Cameroon. AmJTrop Med Hyg 2006, 74:795-797.

61. Moreno M, Vicentez JL, Cano J, Berzosa PJ, de Lucio A, Nzambo S, Bobuakasi L, Buatiche JN, Ondo M, Micha F, Do Rosario VE, Pintoz J, Benito A: Knockdown resistance mutations (kdr) and insecticide susceptibility to DDT and pyrethroids in Anopheles gambia from Equatorial Guinea. Trop Med Int Health 2008, 13:430-433.

62. Koekemoer LL, Spillings BL, Christian RN, Lo TC, Kaiser ML, Norton RA, Oliver SV, Choi KS, Brooke BD, Hunt RH, Coetzee M: Multiple Insecticide Resistance in Anopheles gambiae (Diptera: Culicidae) from Pointe Noire, Republic of the Congo. Vector Borne Zoonotic Dis 2011, 11:1193-200.

63. Chandre F, Darriet F, Manga L, Akogbeto M, Faye O, Mouchet J, Guillet P: Pyrethroid cross resistance spectrum among populations of Anopheles gambiae s.s from Côte d'Ivoire. J Am Mosq Control Assoc 1999, 15:53-59.

64. Donnelly MJ, Corbel V, Weetman D, Wilding GS, Williamson MS, Black WC IV: Does Kdr genotype predict insecticide resistance phenotype in mosquitoes? Trends Parasitol 2009, 25:213-219.

65. Ranson $H$, Jensen B, Vulule JM, Wang $X$, Hemingway J, Collins FH: Identification of a point mutation in the voltage-gated sodium channel gene of Kenyan Anopheles gambia associated with resistance to DDT and pyrethroids. Insect Mol Biol 2000, 9:491-497.

66. Reimer L, Fonjo E, Patchoke S, Diallo B, Lee Y, Ng A, Ndjemai HM, Atangana J, Traore SF, Lanzaro G, Cornel AJ: Relationship between kdr mutation and resistance to pyrethoid and DDT insecticides in natural populations of An. gambiae. J Med Entomol 2008, 45:260-266.

67. Darriet F, N'guessan R, Koffi AA, Konan L, Doannio JM, Chandre F, Carnevale P: [Impact of pyrethrin resistance on the efficacity of impregnated mosquito nets in the prevention of malaria: results of tests in experimental cases with deltamethrin SC](in French). Bull Soc Pathol Exot 2000, 93:131-134.

68. Kolaczinski JH, Fanello C, Herve JP, Conway DJ, Carnevale P, Curtis CF: Experimental and molecular genetic analysis of the impact of pyrethroid and non-pyrethroid insecticide-impregnated bednets for mosquito control in an area of pyrethroid resistance. Bull Entomol Res 2000 90:125-132.

69. N'Guessan R, Corbel V, Akogbéto M, Rowland M: Reduced efficacy of insecticide-treated nets and indoor residual spraying for malaria control in pyrethroid resistance area, Benin. Emerg Infect Dis 2007, 13:199-206.

70. Corbel V, N'Guessan R, Brengues C, Chandre F, Djogbenou L, Martin T, Akogbéto M, Hougard JM, Rowland M: Multiple insecticide resistance mechanisms in Anopheles gambia and Culex quinquefasciatu from Benin, West Africa. Acta Trop 2007, 101:207-216.

71. Toto JC, Besnard P, Le Mire J, Almeida DS, Dos Santos MA, Fortes F, Foumane V, Simard F, Awono-Ambene HP, Carnevale P: [Preliminary evaluation of the insecticide susceptibility in Anopheles gambiae and Culex quinquefasciatus from Lobito (Angola), using WHO standard assay] (in French). Bull Soc Pathol Exot 2011, 104:307-12.

72. Nwane P, Etang J, Chouaibou M, Toto JC, Kerah-Hinzoumbé C, Mimpfoundi R, Awono-Ambene HP, Simard F: Trends in DDT and pyrethroid resistance in Anopheles gambia s.s. populations from urban and agro-industrial settings in southern Cameroon. BMC Infect Dis 2009, 9:163.

doi:10.1186/1475-2875-11-40

Cite this article as: Mourou et al:: Malaria transmission in Libreville: results of a one year survey. Malaria Journal 2012 11:40.

\section{Submit your next manuscript to BioMed Central and take full advantage of:}

- Convenient online submission

- Thorough peer review

- No space constraints or color figure charges

- Immediate publication on acceptance

- Inclusion in PubMed, CAS, Scopus and Google Scholar

- Research which is freely available for redistribution

Submit your manuscript at www.biomedcentral.com/submit
Biomed Central 